2002

\title{
America's Death Penalty: Just Another Form of Violence
}

John Bessler

University of Baltimore School of Law, jbessler@ubalt.edu

Follow this and additional works at: http://scholarworks.law.ubalt.edu/all_fac

Part of the Constitutional Law Commons, and the Law Enforcement and Corrections Commons

\section{Recommended Citation}

America’s Death Penalty: Just Another Form of Violence, 82 Phi Kappa Phi Forum 13 (Winter 2002)

This Article is brought to you for free and open access by the Faculty Scholarship at ScholarWorks@University of Baltimore School of Law. It has been accepted for inclusion in All Faculty Scholarship by an authorized administrator of ScholarWorks@University of Baltimore School of Law. For more information, please contact snolan@ubalt.edu. 


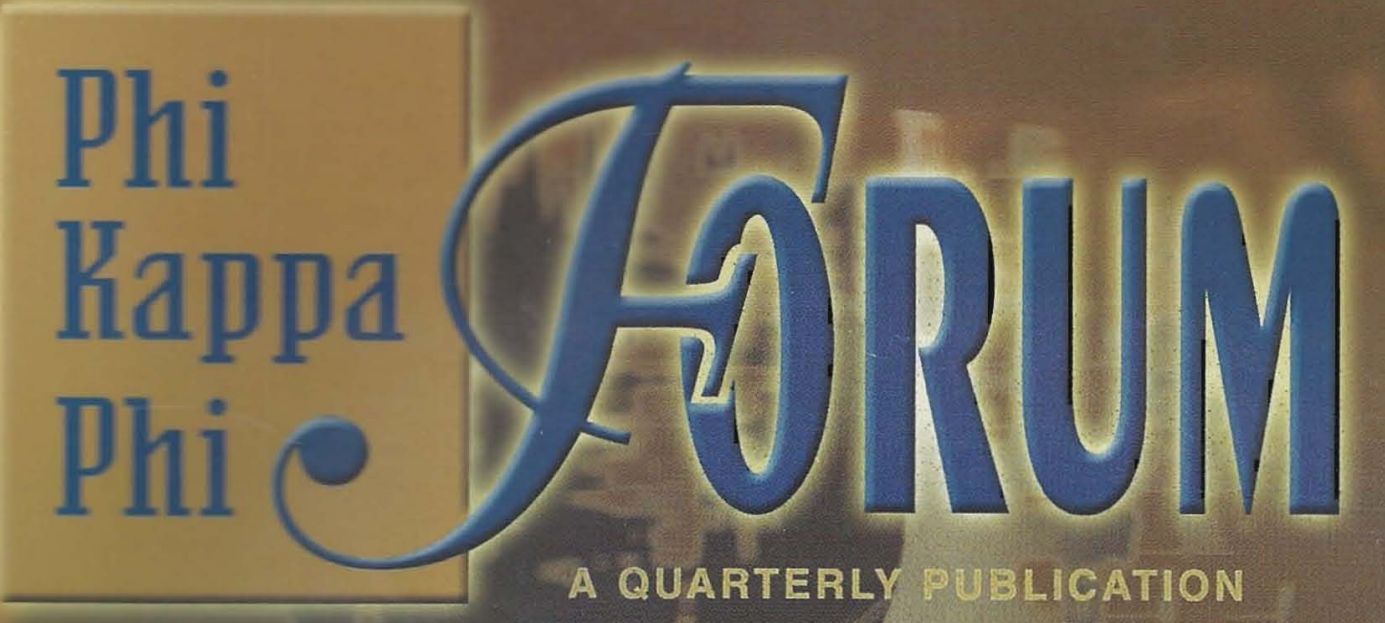

\section{Winter 2002}
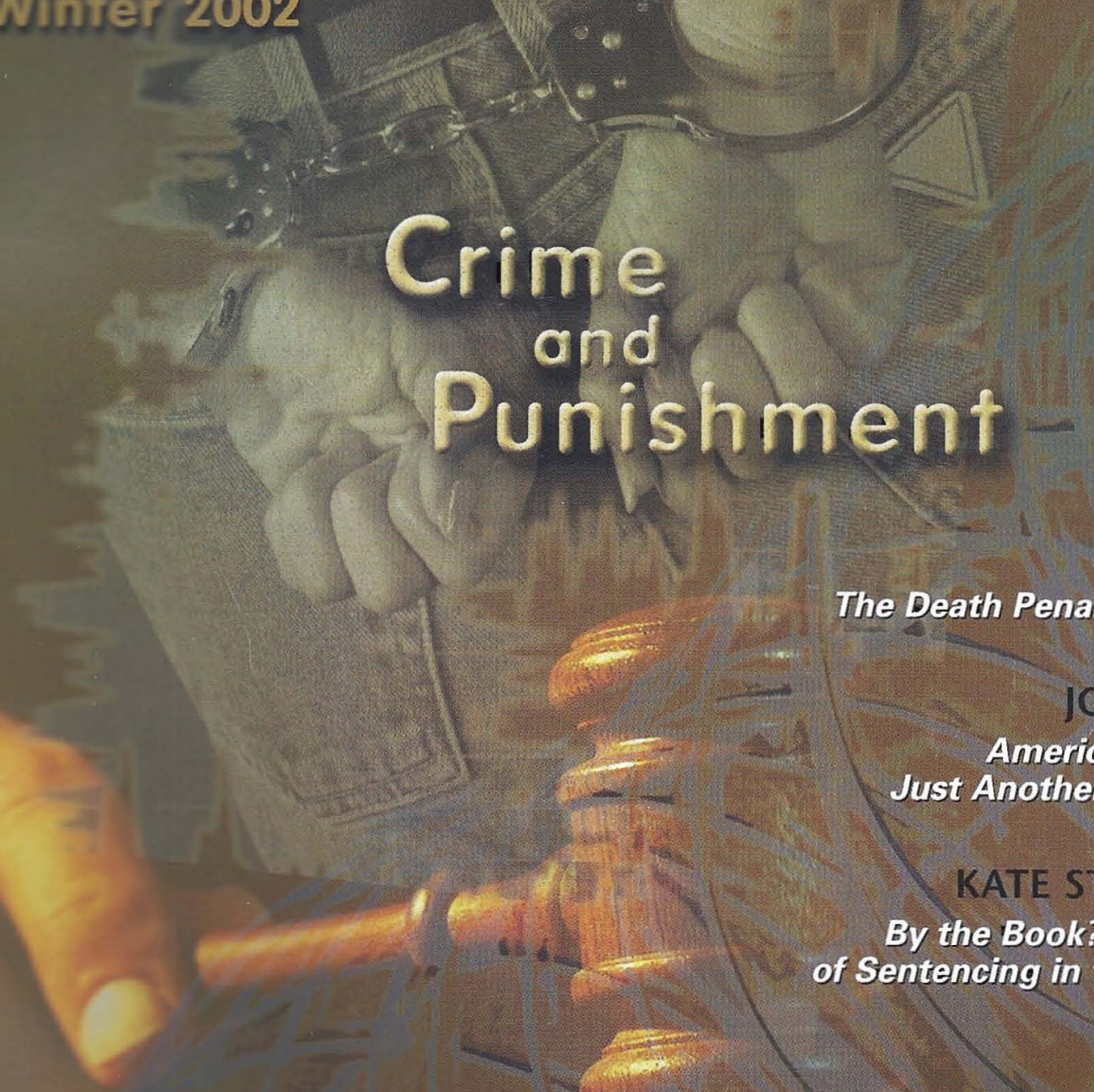

PAUL H. RUBIN

The Death Penalty and Deterrence

JOHN D. BESSLER America's Death Penalty: Just Another Form of Violence

KATE STITH-CABRANES

By the Book? The New Regime of Sentencing in the Federal Courts

ROBERT BATEY

Mandatory Minimum Sentencing: A Failed Policy

MARC MAUER The Social Cost of Amreriga's Race to Incarcerate 


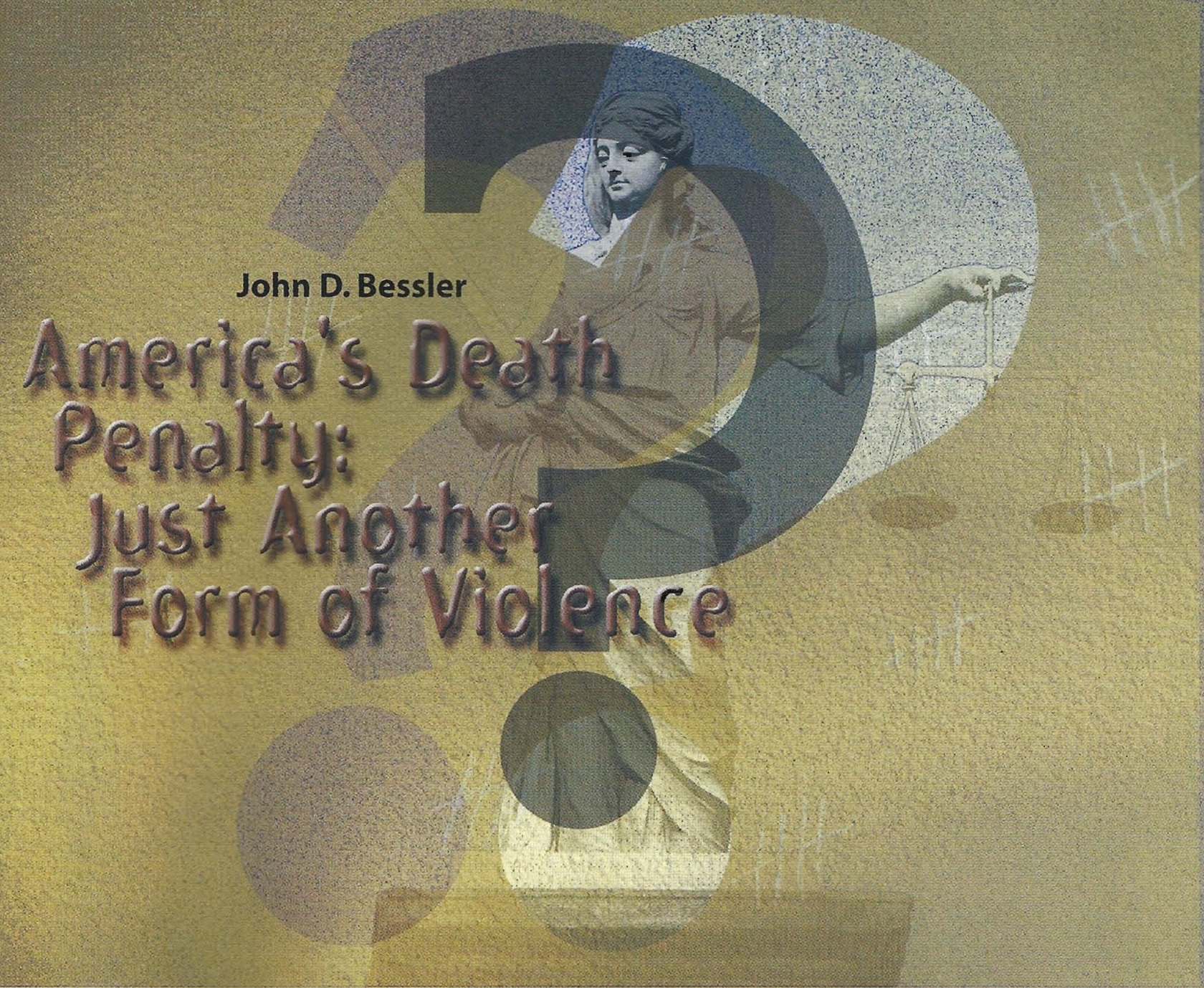

T

he September 11 terrorist attacks on New York City's World Trade Center buildings profoundly affected everyone. The images of smoke billowing from the twin towers, people plummeting hundreds of feet to their deaths, and then the collapse of the skyscrapers themselves, are gruesome and unforgettable. The coordinated terrorist plot, with hijacked planes also crashing into the Pentagon and in Pennsylvania, claimed thousands of lives even as the attacks steeled the world's resolve to fight international terrorism. As we mourn the loss of life, one question that will remain unanswered for some time is the extent to which the terrorist attacks will affect America's domestic anti-death penalty movement; which appeared to be gaining strength in the months before that fateful day.

In the aftermath of the hijackings and the mailing of deadly letters containing anthrax spores, the American people face a host of new challenges. How do we defend ourselves against future terrorist attacks while protecting the constitutional rights of Arab Americans? How do we bring Osama bin Laden and terrorists in al Qaeda to justice, yet not kill hundreds of innocent Afghan civilians in the process? And how should we administer justice to those who killed, harbored terrorists, or facilitated the terrorist attacks who are not themselves killed in the military campaign in Afghanistan? Openly or in secret? The answers to these questions are not trivial, for the whole world is watching what we do and how we conduct ourselves. Just what kind of example will America's government set for the rest of the world? 
Although the world changed on September 11, my firm conviction is that we must not allow acts of terrorism to change our aspirations for a nonviolent society and a lasting global peace. The terrorists, of course, must be brought to justice, but on the home front and abroad Americans must act to reduce violence and human suffering, which are all too often a root cause of violence. In other words, as we tighten airport security and make the U.S. mail safe for everyone to use, we also must take concrete steps to reduce gun crimes and poverty; to address the global threat of chemical, biological, and nuclear weapons; and to eliminate the use of land mines. The death penalty - already abolished in Europe - needs to be done away with as well.

\section{THE DEATH PENALTY IN A VIOLENT SOCIETY}

W Thile many people are sure to call for the death penalty's widespread use after the September 11 terrorist attacks, my own opposition to capital punishment remains unchanged. For me, even in the post-September 11 world, America's death penalty continues to be just another form of violence in an already too-violent society. The problems with the death penalty - the conviction of the innocent, racial discrimination in its application, and the abysmal quality of representation most death-row inmates received at their trials - are legion and have certainly not changed since September 11, and no past or future terrorist attack will affect those realities. Elected officials such as Illinois Governor George Ryan had compelling reasons before September 11 to call for a moratorium on executions, and none of those reasons has gone away. Indeed, so long as the death penalty exists, there will be men like Anthony Porter, one of many death-row inmates recently exonerated in Winois alone, who are sent to death row in error.

When crimes of violence such as murder, rape, and assault are committed, any just system of laws obviously demands that the perpetrators be punished. This makes perfect sense. Maintaining public safety is one of the government's most important obligations, and justice requires that criminals be held accountable for their actions. Just as Osama bin
Laden and terrorist networks around the globe cannot be allowed to continue to operate, anyone who murders, rapes, stabs, or shoots someone must go to prison after guilt is established. The whole purpose of incarcerating criminals is, after all, to eliminate the risk of future acts of violence in society at large.

What makes no sense to me is for a government that already has a criminal in custody to use violence - that is, the death penalty - to try to reduce violence. Using capital punishment only sends the misguided message to members of society that killing already-incarcerated criminals can somehow solve the problem of violence in American life. Statistics and history, in fact, show that just the opposite is true; when the death penalty is used, it tends to brutalize society, not make our lives any safer. While American death-penalty laws may give some a false sense of security, only incarcerating offenders and taking steps to prevent violence will make us safer in the end. Timothy McVeigh's execution did not put a stop to acts of terrorism on American soil, just as death penalty laws do not stop homicides in Dallas or Houston and did not deter suicidal fanatics from hijacking commercial airliners and killing thousands of innocent people in a single day.

I prefer life-withoutparole sentences to the death penalty because capital punishment has a corrosive influence on any society, and there is no evidence that the death penalty really does anything to fight crime. In fact, a recent study commissioned by The New York Times examined FBI data and found that death-penalty states' average murder rates consistently exceeded those of non-death-penalty states. The study reached the very disturbing conclusion that, over the last twenty years, death-penalty states' homicide rates have been, on a per capita basis, an astonishing 48 percent to 101 per-

cent higher than in non-death-penalty states. Of America's twelve non-death-penalty states, ten have murder rates that are below - often far below the national average.

The State of Minnesota, where I live, for instance, abolished capital punishment in 1911 and yet has one of the lowest violent-crime rates in the 
country. While the national homicide rate was 6.3 murders per 100,000 people in 1998, Minnesota's rate that year was less than half that figure; in contrast, active death-penalty states such as Texas and Louisiana regularly have some of the country's highest murder rates. I think anyone who fairly considers the evidence should be extremely troubled by the fact that, year after year, America's death-penalty states have higher homicide rates than do non-death-penalty states. Obviously, many factors can affect a state's homicide rate. However, these compelling statistics - indeed, logic itself - compel the conclusion that the death penalty is, at bottom, really nothing more than part of a culture (still prevalent in many places) that condones the use of violence.

\section{EXECUTIONS OUT OF SIGHT}

$\mathrm{T}$ hat executions are brutalizing to American society was actually clear at least more than a century ago. Indeed, in the $1830 \mathrm{~s}$, American states began moving executions out of public squares because of the general disorder that often prevailed at them.

This trend started in northeastern states and then gradually spread to all parts of the country. Midday executions on the public commons were, over the next hundred years, gradually replaced by after-dark executions that, by the late 1930 s, universally took place behind prison walls. State laws specifically limited attendance at executions to a few official witnesses, and county sheriffs and prison wardens regularly barred children and women from attending them. In the twentieth century, new laws were passed throughout the country forbidding television cameras from filming these events.

Because civic leaders saw public executions as corrupting morals, many states even passed laws in the nineteenth century forbidding newspapers from printing any details of executions. Public executions, it was recognized, often drew pick-pockets and drunken spectators, and state legislators concluded that if executions were creating unintended consequences, so too were newspaper accounts of hangings. Thus, in many locales such as Arkansas, Minnesota, New York, and Virginia, only the bare fact that a criminal was executed could be printed or published. Any reporter who violated one of these laws and described an execution in print could be criminally prosecuted and jailed.
To further restrict public access to information about executions, many states actually mandated by law - as some still do - that executions take place "before sunrise." The constitutionality of one of these laws, dubbed by its contemporaries as the "midnight assassination law," was upheld by the Minnesota Supreme Court in 1907. That court ruled that the "evident purpose of the act was to surround the execution of criminals with as much secrecy as possible, in order to avoid exciting an unwholesome effect on the public mind." Executions "must take place before dawn, while the masses are at rest," the court held, to give effect to the law's "purpose of avoiding publicity."

The modern-day contention by some that executions deter crime better than life-without-parole sentences is thus totally at odds with both American history and the facts. If executions were such a wonderful deterrent, why would the government choose to hide them from public view and even pass laws to prohibit the dissemination of news about them?

Today, most American executions still receive very little media attention, with the exception of higher-profile ones such as Timothy McVeigh's. Of the 313 executions that were carried out in the United States from 1977 to 1995, more than 82 percent of them actually took place between 11:00 P.M.

\section{What I find so troubling about the death penalty is that our most valued democratic institutions (the judiciary, the Congress and state legislatures, and the executive branch) all sanction (and are tainted by) the very same horrific act - senseless killing - that we so rightfully decry when} terrorists or murderers commit their crimes. and 7:00 A.M., when most people are asleep. More than 50 percent of those executions took place between midnight and 1:00 A.M., with laws in Louisiana and Delaware specifically requiring that executions take place between midnight and 3:00 A.M. Because they are conducted in private, American executions are, to most people, mere abstractions, not tangible events that would seem more real if they were broadcast on the nightly news. Ironically, while we see horrific film footage on CNN of the Taliban executing a civilian in an Afghan soccer stadium, American executions, without exception, remain hidden from public view 
Although executions are kept out of sight by state legislators and the federal government, it must never be forgotten that when a democratic government takes a life, it does so on behalf of its citizens. The United States of America is, after all, governed by "We, the People." Our own elected representatives pass death-penalty laws, ordinary Americans sit on juries that impose death sentences, and the public's money pays for lethal-injection machines and executioners' salaries. What I find so troubling about the death penalty is that our most valued democratic institutions (the judiciary, the Congress and state legislatures, and the executive branch) all sanction (and are tainted by) the very same horrific act — senseless killing — that we so rightfully decry when terrorists or murderers commit their crimes.

\begin{tabular}{c}
\hline CURTAILING VIOLENCE \\
BY COMMITTING VIOLENCE? \\
\hline
\end{tabular}

Tn the wake of terrorist attacks, workLplace shootings, carjackings, or gun violence such as that which took place at Columbine High School, effective measures can and should be taken to curtail violence. More sophisticated computer systems to track offenders, beefed-up security at public places, and better regulation of firearms are all steps that we can take to make the United States a safer place in which to live and work. Although lethal injections have largely sanitized executions, it cannot be doubted that the death penalty is a form of violence. Whether carried out by firing squad, hanging, electrocution, the gas chamber, or lethal injection, the result is the same: the killing of human life.

In wartime or when someone acts in self-defense to preserve his or her own life, the use of violence can be justified to protect life. World War II, for example, was fought to stop Nazi aggression and end the Holocaust. But when a government already has someone in prison, what purpose is served by an execution? All an execution does is inject more violence into a society. Because the government should be setting an example for its people, executions are especially counterproductive. The need for public safety and what should be any government's goal - that is, a nonviolent society - can be easily reconciled by making life-without-parole sentences the maximum penalty allowed by law for murder.
The amount of violence in American society, whether on the streets or as seen on prime-time television, is astonishing. We see hijacked planes piloted into the World Trade Center and bursting into flames; we see murder scenes with yellow police tape on the evening news; and family-friendly television programming often seems to be a rare commodity. The media, acting under the guarantees of the First Amendment, must be allowed to report and expose acts of violence. However, the sheer amount of violence we face does not mean that we should inject even more violence into our lives by using the death penalty. Indeed, everyone from parents to our nation's lawmakers must play a role in shaping a better, more nonviolent future for our children.

When our country's governors or judges sign death warrants for people already confined in prison, they send the wrong message to our nation's youth. Do we really want some of our most educated members of society, who should be role models of the highest order, telling our children that killing locked-up criminals is the way to solve problems? We certainly do not hold up executioners as role models for our children, yet when executions occur, aren't all members of our society in some way responsible for what those executioners are doing? It is, after all, our own laws that allow executions to happen within our borders. If anything, the death penalty only perpetuates the mistaken notion that state-sanctioned executions can somehow curtail violent crime in the United States. Just as the NAACP successfully crusaded against lynching in the last century, it is time for all of us in this century to work to do away with state-sponsored executions.

If America is to have a safer society, we must stop seeing the death penalty as a "crime-fighting" tool, which it clearly is not. Instead, we must start seeing 
capital punishment for what it is: just another form of violence in our society. Thus, as we grapple with the thorny issues of how to bring heavily armed terrorists in Afghanistan to justice, America's domestic political agenda cannot be allowed to stand still. The abolition of America's death penalty is, in fact, one way already within our grasp to reduce violence. Instead of putting needles into criminals who are brain-damaged, mentally retarded, or who do not share our value for human life, our crime-fighting efforts should focus on real solutions such as tougher gun-control laws, stiffer penalties for violent offenders, better child-protection laws, and combating truancy to keep kids in school and out of gangs.

In the final analysis, the death penalty does nothing more than validate the use of senseless violence, which is not a wise or sensible thing to do in the first place. As Martin Luther King, Jr., warned: "The ulti- mate weakness of violence is that it is a descending spiral, begetting the very thing it seeks to destroy." America's death penalty, inflicted after murders have already been committed, only creates more violence and represents yet another roadblock that we must dismantle if we are ever to realize King's dream of a nonviolent society based on the principles of equality and respect for human life.

John Bessler is an attorney and an adjunct professor of law at the University of Minnesota Law School. He is the author of Death in the Dark: Midnight Executions in America, published by Northeastern University Press, and Legacy of Violence: Lynch Mobs and Executions in Minnesota, forthcoming from the University of Minnesota Press.

\title{
FIVE SUNDOWN SKIES IN AUGUST
}

\author{
(after David Wagoner) \\ 1 \\ A once-ago boy, sobbing, atop his sister's \\ Grave - fingers, clawing the ground. \\ 2
}

The old man, asleep on the boathouse porch,

A red $\&$ white bobber, just now, tugged below surface.

3

Golden ears of corn, plump \& roasting on an open fire.

Cows, huddled together, beneath walnut boughs.

4

Heat lightning, emptying over lemon-green

Hayfields. Weather-beaten cross above a vine-strangled church.

5

A family of Amish walking through heavens

Of dustclouds, swirling, from a passing Greyhound bus.

ROBERT NAZARENE

Robert Nazarene's poetry appears or is forthcoming in: The Beloit Poetry Journal, Boulevard, Callaloo, Green Mountain Review, Ploughshares, and elsewhere. He is a graduate of the Georgetown University School of Business Administration and serves on the board of The St. Louis Poetry Center. 